культури учня основної школи і рівнем сформованості читецьких компетенцій у процесі вивчення художньої літератури.

\title{
Література
}

1. Бахтин М. М. Вопросы литературы и эстетики / М. М. Бахтин. - М. : Художественная литература, 1975. - 504 с. 2. Зинченко В. П. Размышления о душе и ее воспитании (час души) / В. П. Зинченко // Вопросы философии. - 2002. - №2. - С. 119-136. 3. Лихачев Д. Б. Теория эстетического воспитания школьников / Б. Б. Лихачов. - М., 1985. - 176 с. 4. Подольська Є. А. Культурологія : [навч. посіб.] / Подольська Є. А., Лихвар В. Д., Іванова К. А. - К. : Центр навчальної літератури, 2003. - 288 с. 5. Рубинштейн С. Л. Основы общей психологии : в 2 т. / С. Л. Рубинштейн ; АПН СССР. - М. : Педагогика, 1989. - Т. 2. - 1989. - 323 с. 6. Сухомлинський В. О. Вибрані твори : в 5-ти т. Серце віддію дітям. Народження громадянина. Листи до сина / В. О. Сухомлинський. - К. : Радянська школа, 1977. - Т.3. - 670 с. 7. Флоренская Т. А. Проблема психологии катарсиса как преобразования личности / Т. А. Флоренская // Психологические механизмы регуляции социального поведения. - М. : Наука, 1979. - С.151-174. 8. Шацкий С. Т. Избранные педагогические сочинения : в 2 т./ С. Т. Шацкий. - М. : Педагогика, 1980. - Т.2. - 416 с. 9. Эстетическое воспитание молодежи средствами искусства / под ред. Бутенко В. Г. - М., 1991. 242 с. 10. Якобсон П. М. Психология чувств / П. М. Якобсон / АПН РСФСР, Ин- т психологии. М. : Изд- во АПН РСФСР, 1956. - 237 с.

УДК 908(07):5

\author{
А. А. Самолюк, \\ аспірант, \\ ДВНЗ «Переяслав-Хмельнииький державний \\ педагогічний університет імені Григорія Сковороди»
}

\section{ТЕНДЕНЦІЇ РОЗВИТКУ КРАЕЗНАВЧОЇ ОСВІТИ У ЗМІСТІ МЕТОДИЧНИХ РЕКОМЕНДАЦІЙ ДЛЯ ВЧИТЕЛІВ ЗОШ ІЗ ФОРМУВАННЯ ТВОРЧОЇ АКТИВНОСТІ УЧНІВ ОСНОВНОЇ ШКОЛИ У ПРОЦЕСІ ТУРИСТСЬКО-КРАЄЗНАВЧОЇ РОБОТИ}

Самалюк А. А. Тенденції розвитку краєзнавчої освіти у змісті методичних рекомендацій для вчителів зош із формування творчої активності учнів основної школи у процесі туристськокраєзнавчої роботи.

У статті розкрито тенденції розвитку краєзнавчої освіти як складника природознавчої освіти. Доведено, що оволодіння краєзнавчим матеріалом сприяє активізації творчого потенціалу в учнів основної школи у процесі туристсько-краєзнавчої роботи.

Ключові слова: краєзнавча освіта, учні основної школи, творча активність, творчий потенціал, туристсько-краєзнавча освіта.

Самалюк А. А. Тенденции развития краеведческого образования в содержании методических рекомендаций для учителей ОСШ по формированию творческой активности учащихся основной школы в процессе туристическо-краеведческой работы.

В статье раскрыты тенденции развития краеведческого образования как составляющей природоведческого образования. Доказано, что овладение краеведческим материалом способствует активизации творческого потенциала у учеников основной школы в процесс се туристическо-краеведческой работы.

Ключевые слова: краеведческое образование, ученики основной школы, творческая активность, творческий потенциал, туристически-краеведческое образование.

Samalyuk A. A. Trends in local history education in the content of methodological recommendations for teachers of secondary schools for the purposes of formation of creative activity of basic school students in the tourism and local history work.

The article reveals trends in local history education as a component of the Natural History of Education. Proved that mastering local history materialom sposobostvuet enhance creativity among elementary school students in the process se-tourist local history work.

Key words: local history education, primary school students, creativity, creative potentsial, turichticheski-regional studies education. 
Проблема особистісного зростання дитини, активізація іiі творчої активності у всіх сферах іiі життєдіяльності в загальноосвітньому навчальному закладі, за його межами у позакласній виховній роботі і сім'ї починаючи 3 середини минулого століття, була об'єктом уваги багатьох психолого-педагогічних напрямів (психодинамічного, диспозиціонального, соціально-когнітивного тощо). Однак, у розумінні сутності феномену «зростання (активізація) творчої активності особистості» смислові акценти психологів і педагогів не збігалися. Водночас спільною у більшості наукових підходів було визнання ціннісної самореалізація власних природних потенціалів особистості (І. Булах, Л. Виготський, С. Рубінштейн, О. Леонтьєв, Л. Божович, Г. Оллпорт, А. Маслоу, К. Роджерс та інші).

Актуальною в цьому контексті $є$ думка В. Сухомлинського, який стверджував, «підліток стає справжньою людиною лише тоді, коли він уміє пильно вдивлятися не тільки в навколишній світ, а й у самого себе, коли він прагне пізнати не тільки речі і явища навколо себе, а й свій внутрішній світ, коли сили душі спрямовані на те, що зробити самого себе кращим, досконалішим».

Психолого-педагогічні основи формування знань, умінь і навичок взаємодії та вивчення об'єктів навколишнього середовища як соціального, так і природного охарактеризовано у працях Л. Виготського, Д. Ельконіна, О. Киричука, О. Леонтьєва, А. Маслоу, Г. Оллпорта, К. Роджерса, С. Рубінштейна та інших.

Активність дитини як суб'єкта процесу навчання i виховання частково охарактеризовано також у працях А. Асмолова, С. Архангельского, І. Беха, В. Лозової, А. Макаренка, М. Сметанського, Т. Сущенко, Г. Троцко та інших.

Історико-педагогічні дослідження в яких характеризуються аспекти організації та здійснення краєзнавчої роботи, активізації творчого потенціалу дитини в процесі практичної діяльності в довкіллі, напрями та зміст такої роботи в навчальних закладах України в різні історичні періоди знайшли своє відображення у працях Л. Бабенка, В. Бенедюк, Г. Гуменюк, М. Костриці, Т. Міщенко, В. Прокопчук, Т. Самоплавської, П. Тронько, М. Соловея та інших.

Розгляд краєзнавчої освіти у якості цілісних утворень певного етапу соціокультурного життя визначає застосування діалектико-матеріалістичної методології та відповідних загальнонаукових методів, зокрема системно-діяльнісного пізнання, які останнім часом використовуються у дослідженні складнодинамічних соціокультурних явищ.

Mета статmi - розкрити тенденції розвитку краєзнавчої освіти у змісті методичних рекомендацій для вчителів ЗОШ із формування творчої активності учнів основної школи у процесі туристсько-краєзнавчої роботи.

Розкриття закономірностей розвитку краєзнавчої педагогічної освіти 3 метою іiі ефективного управління та прогнозування стратегії розвитку, стає можливим лише за умови пізнання природи, суті, функцій, структури краєзнавчої освіти в цілому, адже система осмислення краєзнавчої освіти та її підсистеми - краєзнавчої педагогічної освіти не $є$ самоціллю, оскільки «не може бути аналітичного вивчення будь-якого окремого об’єкту без точної ідентифікації цього окремого у більшій системі» [1, с. 56]. Оптимальний шлях розв'язання цього завдання - підхід до системи, що вивчається, як до частини певної метасистеми, тобто зовні, із середовища, до якого вона вписана і в якому вона функціонує. 3 огляду на це дослідження тенденцій краєзнавчої освіти повинно здійснюватися на фоні розгляду цілісної краєзнавчої освіти, оскільки відрив складової від цілого призводить до неповного наукового опису.

Виходячи 3 того, що краєзнавча освіта спрямована на конкретну людину, пов'язана 3 їі внутрішнім світом та своєрідним природно-культурним середовищем, здійснюється в історично визначеному просторовому окресленні, їі слід розглядати у системі об'єктивної реальності в межах діалектико-матеріалістичної методології.

У контексті нашого дослідження заслуговує на увагу підхід М. Кагана, який у цілісному системному утворенні взаємопов'язаних форм буття природа - людина - 
суспільство - культура виокремлює людську діяльність як системо утворювальний чинник. Продуктом діяльності як способу існування людини є суспільство (система суспільних відносин людей) та культура (сукупність результатів і способів людської активності). Діяльність, будучи безпосередньою ланкою зв'язку людини з природою і суспільством, надає людині біосоціокультурної будови [2, с. 85-86; 5, с. 12].

Надбіологічне визначення діяльності забезпечує культура, яка накопичує людський досвід і спрямовує його на формування людини і відтворення суспільства. Тому суспільну форму життя реалізують як генетичні, так і культурні механізми при визначальноперетворюючій ролі останніх. Набуття особистістю протягом свого життя відбувається через засвоєння наявного соціокультурного досвіду.

Розглянута структура функціонування культури й уявлення про позабіологічне формування людини уможливлюють здійснення системного аналізу суспільного буття, у якому опанування і передавання життєвого досвіду становить головну умову існування та відтворення людини. 3 розвитком суспільної форми життя об'єктивно одержує розвиток процес передачі накопиченої попередніми поколіннями соціокультурної інформації, який може здійснюватися двома шляхами: стихійно-різноспрямованим та цілеспрямованоорганізованим. Шлях цілеспрямовано-організованого формування культури нових поколінь узагальнюється в освітянську діяльність. Освіта становить вироблений засіб цілеспрямованого окультурення індивідів з метою включення їх в соціокультурне життя. Отже, освітянська діяльність є спеціалізованою складовою в соціальному організмі, необхідною для відтворення суспільного життя [4, с. 12; 5, с. 15].

Принципово важливим в контексті нашого дослідження є також зауваження М. Кагана щодо поняття «спілкування», яке підлягає опануванню шляхом освіти. Культурний феномен спілкування є міжсуб'єктивною взаємодією, що погоджує спільність людей, певний рівень їх духовного єднання та єдності в практичних діях [2].

Задля уточнення сутності краєзнавчої освіти розглянемо визначення поняття «освіта» взагалі. Так, за вітчизняними енциклопедичними джерелами під освітою розуміли «сукупність систематизованих знань, умінь, навичок, поглядів, переконань, набутих в результаті навчання в навчальному закладі або ж шляхом самоосвіти» [3, с. 78; 9, с. 59].

У посібниках з педагогіки освіту визначають, як «обсяг систематизованих знань, умінь і навичок, способів мислення» [8, с. 25], якими оволодівають в процесі навчання. Крім того, вказується на важливість «формування на цій основі світогляду, моральних та інших якостей особистості, розвитку іiі творчих сил і здібностей» [7, с. 9-10]. «Давати людині освіту - це те ж саме, що змінювати іiі, перетворювати, розвивати іiі особистість», адже освіта людини ... «є певним станом усієї психіки людини і перш за все певним співвідношенням та зв'язками емоцій, волі та діяльності з інтелектом» [6, с. 61-62].

Підсумовуємо, що під терміном «освіта» (під ним Й. Песталоцці мав на увазі «формування образу») розуміють «єдиний процес фізичного і духовного формування особистості», який полягає в оволодінні системою [7, с. 18] накопичених минулими поколіннями знань та культурних цінностей, тобто освіта. Остання становить процес засвоєння досвіду, виховання та розвитку, що запрограмований з урахуванням генетичної програми і відповідно до того обсягу передавання культури, які визначаються потребами суспільства.

Одним 3 найважливіших важелів впливу на соціокультурні процеси, що відбуваються в Україні, саме i повинна стати краєзнавча освіта. Забезпечуючи цілеспрямоване передавання регіональних культурних надбань, вона $є$ ефективним засобом соціалізації підростаючого покоління, від якого залежить характер розвитку соціального життя в країні.

Краєзнавча освіта - процес і результат цілеспрямованого формування особистості на основі засвоєння досвіду і традицій регіональної культури. На сучасному етапі розвитку краєзнавчої освіти стає необхідним забезпечення рівнонеобхідних в організації суспільного життя, зокрема в розвитку особистості обов'язково-суспільної та 
індивідуально-варіативної освітніх частин. В освітянській галузі окреслена вимога може бути забезпечена збалансованим поєднанням обов'язкової і варіативної складових освіти [4]. Із цих позицій краєзнавча освіта, стимулюючи одержання конкретними індивідами i людськими спільнотами єдиних суспільно-державних якостей, сприяє утворенню, поперше, регіонально-соціумних цілісностей, в яких у процесі формування людської особистості органічно поєднуються іiї регіонально-соціумне й індивідуально-групове (етнічно-особистісне) становлення, що безпосередньо становить стабілізізаційнодинамізуючий чинник консолідації української нації. По-друге, вимога «всебічного розвитку людини як особистості» ставить питання про охоплення краєзнавчою освітою всіх основних складників регіональної соціально-культурної спадщини. Тобто йдеться про «розвиток усіх видів діяльності, що складають структуру особистості - діяльності перетворювальної, пізнавальної, цілісно-орієнтаційної, спілкування, художньої» [4, с. 70].

Отже, краєзнавча освіта (як загальна, так і спеціальна педагогічна) має охоплювати всі види елементів регіональної культури, що визначають основні види діяльності. 3 цих позицій завдання краєзнавчої освіти сьогодні полягає у досягненні пропорційного, збалансованого, рівноправного співіснування всіх іiі складників за принципом взаємодоповнюваності. Така комплексність для загальної краєзнавчої освіти має забезпечуватись обов'язковим рівнозначним представництвом у іiі змісті кожного 3 основних компонентів, повним охопленням основних видів діяльності комплексом рівноважливих дисциплін. Комплексне урівноваження видових складників освіти повинно поєднуватись з приведенням педагогічних технологій і оцінок у відповідність до основних освітніх компонент.

Краєзнавча освіта, створюючи умови для повноцінного розвитку особистості, $\epsilon$ багатогранним соціально-освітнім явищем і невід'ємною складовою гуманітарної освіти. Утворення і розвиток будь-якої системи спрямовується на те, щоб шляхом ії доцільної організації й постійного удосконалення функцій iї складових досягти підвищення ефективності поставлених цілей.

Відповідно до теорії систем функціональні аспекти в цілому освітянської галузі (функціональний склад освіти, поєднання функцій, їх системоутворювальна повнота тощо) розроблялися Е. Білозерцевим, О. Коопом, Н. Кузьміною, Ф. Філіповим, В. Луговим та іншими.

У результаті розгляду історико-типологічних аспектів українського краєзнавства, основні функції краєзнавчої освіти, завдяки яким вона виникла i розвивається як самостійний культурно-освітній напрям у складі освітянської галузі, слід виводити як 3 умов і потреб соціокультурного життя суспільства, так і конкретного регіону.

3 першою головною тенденцією розвитку краєзнавчої освіти (яка полягає у

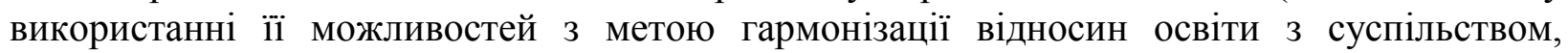
людиною, природою, культурою) пов'язана реалізація її зовнішньої функції, спрямованої на забезпечення відродження і посилення життєвої відповідності освітньої сфери.

Як засвідчило проведене нами дослідження, характерною особливістю системи краєзнавчого навчання $є$ більш якісний підхід до виявлення результатів навчання. У запропонованій нами системі особлива увага звертається не тільки на засвоєння учнями матеріалу навчальної програми, але і на їх особистісно-творчий розвиток, зокрема на:

1. Творчу ініціативу і навчальну дисципліну, про що свідчить зростання в учнів мотивації до краєзнавчого навчання. Діяльність, що пов'язана з навичками самостійного одержання знань, формує в учнів необхідність регулярного навчання і самоосвіти.

2. Розвиток емоційно-вольових якостей, зокрема здатності до стимулювання навчальної діяльності, про що свідчать уміння учнів здійснювати вольові зусилля для виконання навчальної діяльності, виявляючи при цьому самокритичність.

3. Особистісно-ціннісну орієнтацію, спрямовану на усвідомлення своєї самоцінності, що сприяє закладанню співдружності і співтворчості в навчальному процесі. 
4. Потяг до навчального спілкування на основі розвитку почуття співдружності 3 однокласниками, що виявляється у прагненні брати участь у спільних справах.

У публікації розкрито тенденції розвитку краєзнавчої освіти у змісті методичних рекомендацій для вчителів ЗОШ із формування творчої активності учнів основної школи у процесі туристсько-краєзнавчої роботи (самостійний культурно-освітній напрям у складі освітянської галузі; чинник здійснення діяльності перетворювальної, пізнавальної, цілісно-орієнтаційної, спілкування, художньої, що сприяє вияву творчого потенціалу особистості). Розкриття закономірностей розвитку краєзнавчої освіти 3 метою іiі ефективного управління та прогнозування стратегії розвитку, стає можливим лише за умови пізнання природи, суті, функцій, структури краєзнавчої освіти в цілому.

\section{Література}

1. Анохин П. К. Избранные труды: Философские аспекты теории функциональной системы / П. К. Анохин. - М. : Наука, 1978. - 400 с. 2. Каган М. С. Системный подход и гуманитарное знание : Избранные статьи / М. С. Каган. - Л. : Изд-во Ленин. ун-та, 1991. - 384 с. З. Леднев В. С. Содержание образования: сущность, структура, перспективы / В. С. Леднев. - М. : Высш. шк., 1991. - 224 с. 4. Луговий В. І. Педагогічна освіта в Україні / В. І. Луговий. - К. : МАУП, 1994. 196 с. 5. Макареня А. А. Методологические основы создания культуротворческой среды подготовки учителя : автореф. дис. на стискание ученой степени докт. пед. наук : 13.00.01/ А. А. Макареня. - М., 1998. - 42 с. 6. Оконь В. Введение в общую дидактику / В. Оконь / [пер. с польского Л. Г. Кашкуревича, Н. Г. Горина]. - М. : Высш.шк., 1990. - 382 с. 7. Педагогика : [учебное пособие для студентов пед. ин-тов] / Ю. К. Бабанский, В. А. Сластенин, Н. А. Сорокин и др. / под ред. Ю. К. Бабанского. - М. : Просвещение, 1988. -479 с. 8. Подласый И. П. Педагогика : [учебник для студ. высш. учеб. завед.] / И. П. Подласый. - М. : Просвещение, 1996. - 432 с. 9. Український радянський енциклопедичний словник : в 3 т. / ред. кол. : Бабичев К. С., Дзеверін І. О., Денисов А. Ф. та ін. - Т.2. - К. : УРЕ, 1987. - С. 59.

УДК 78(07):373.5

Т. Д. Фурдак, ст. викладач,

Криворізький педагогічний інститут ДВНЗ «Криворізький наиіональний університет»

\section{СУТНІСТЬ ТА ОСОБЛИВОСТІ МУЗИЧНОГО СПРИЙМАННЯ УЧНІВ НА УРОКАХ МУЗИки}

Фурдак Т. Д. Сутність та особливості музичного сприймання учнів на уроках музики.

У статті грунтовно розкрито сутність та особливості музичного сприймання учнів на уроках музики. На основі теоретичного аналізу досліджень науковців, багаторічного особистого спостереження, досвіду викладачів вищих навчальних закладів та вчителів музики загальноосвітніх шкіл пропонуються етапи організації умов процесу вміння усвідомлено сприймати музичний твір учнями.

Ключові слова: музичне сприймання, емоційно-свідоме сприймання, пізнання, пізнавальний інтерес.

Фурдак Т. Д. Сущность и особенности музыкального восприятия учеников на уроках музыки.

В статье расскрыта сущность и особенности музикального восприятия учеников на уроках музыки. На основании теоретического анализа исследований учених, личных многолетних наблюдений, опыта педагогов высших учебных заведений, a также учителей общеобразовательных школ предлагаются этапы организации условий процесса умения сознательно воспринимать музыкальное произведение учениками.

Ключевые слова: музыкальное восприятие, эмоционально-сознательное восприятие, познание, познавательный интерес.

Furdak T. D. Essence and features musical perception of pupils in music. 